\title{
The Initiation of Th2 Immunity Towards Food Allergens
}

\author{
Yosef Ellenbogen ${ }^{1,+}{ }^{10}$, Rodrigo Jiménez-Saiz ${ }^{1,+}$, Paul Spill ${ }^{1}$, Derek K. Chu ${ }^{2}$, Susan Waserman ${ }^{2}$ \\ and Manel Jordana ${ }^{1, *}$ \\ 1 McMaster Immunology Research Centre (MIRC), Department of Pathology \& Molecular Medicine, \\ McMaster University, MDCL 4013, 1280 Main St W, Hamilton, ON L8N 3Z5, Canada; \\ yosef.ellenbogen@medportal.ca (Y.E.); jimenez@mcmaster.ca (R.J.-S.); spillp@mcmaster.ca (P.S.) \\ 2 Department of Medicine, McMaster University, Hamilton, ON L8N 3Z5, Canada; \\ chudk@mcmaster.ca (D.K.C.); waserman@mcmaster.ca (S.W.) \\ * Correspondence: jordanam@mcmaster.ca \\ + These authors contributed equally to this work.
}

Received: 3 April 2018; Accepted: 7 May 2018; Published: 12 May 2018

\begin{abstract}
In contrast with Th1 immune responses against pathogenic viruses and bacteria, the incipient events that generate Th2 responses remain less understood. One difficulty in the identification of universal operating principles stems from the diversity of entities against which cellular and molecular Th2 responses are produced. Such responses are launched against harmful macroscopic parasites and noxious substances, such as venoms, but also against largely innocuous allergens. This suggests that the established understanding about sense and recognition applied to Th1 responses may not be translatable to Th2 responses. This review will discuss processes and signals known to occur in Th2 responses, particularly in the context of food allergy. We propose that perturbations of homeostasis at barrier sites induced by external or internal subverters, which can activate or lower the threshold activation of the immune system, are the major requirement for allergic sensitization. Innate signals produced in the tissue under these conditions equip dendritic cells with a program that forms an adaptive Th2 response.
\end{abstract}

Keywords: Th2 immunity; food allergy; allergic sensitization; allergens; alarmins; initiation of allergy; IgE; allergic disease

\section{Introduction}

Th2 responses are generated against structurally diverse entities, including macroscopic parasites, noxious substances (e.g., poisons and venoms), and largely innocuous antigens, such as food allergens [1,2]. Therefore, it is difficult to delineate universal operating principles governing their development. The diversity of entities against which $\mathrm{Th} 2$ responses are generated also suggests that the established understanding regarding the sense and recognition of Th1 responses to viruses and bacteria is likely not translatable to Th2 responses. Furthermore, as noted by Netea et al., the initiation of Th2 immunity requires the engagement of the entire tissue including not only immune cells but also tissue structural cells, such as epithelial cells [3]. Additionally, deciphering the signals that emerge from the tissue microenvironment may provide insights about the initiation of Th2 responses. This review will discuss processes and signals that initiate Th2 immunity in the context of food allergy. First, we introduce what is known about the acquisition of a Th2 identity. Second, we discuss the extent to which food allergens are innocuous, concluding that their inherent immunogenicity likely plays only a minor role. Thus, we propose that concomitant events that subvert the steady state of the microenvironment produce signals that prime the immune surveillance system to react to allergens 
present at the site. Third, we consider signals known to be produced at barrier sites (skin and mucosa) that equip dendritic cells (DCs) with the ability to facilitate the generation of Th2 immunity. Fourth, we introduce the concept that elicitation of Th2 responses to largely harmless allergens may also occur as a result of specific internal, i.e., genetic, alterations that decrease the threshold of activation of the immune system. Ultimately, we argue that allergen-independent, concomitant perturbations that are either internal and/or externally driven subvert tissue homeostasis and play the predominant role in the facilitation of Th2 responses to food allergens.

\section{On the Acquisition of a Th2 Identity}

In the late 1980s, Mosmann et al. transformed the understanding of CD4 T cells by both classifying them based on their cytokine profile upon stimulation and demonstrating their unique functionalities [4]. Essentially, Th1 cells generated IFN- $\gamma$, while Th2 cells produced IL-4 (once referred to as B-cell stimulating factor-1, BSF-1) and IL-5. Subsequently, it became clear that Th1 cells predominated in responses against viruses and intracellular bacteria, while Th2 cells were required for those against extracellular pathogens. It was also proposed that a Th1/Th2 imbalance towards Th2 could be the cause of allergic diseases $[5,6]$. These findings prompted studies to elucidate mechanisms through which naïve CD4 T cells could acquire a Th2 phenotype.

In vitro experiments with naïve CD4 T cells subjected to polyclonal activation showed that IL-2 and IL-4 were critical for Th2 polarization [7,8]. However, two factors, namely, the role of IL-2 in facilitating $\mathrm{T}$ helper differentiation of various subsets (e.g., Th1, Th2, inducible Tregs.) [9] in addition to the identification of IL-4 as the major product of, and specific for Th2 cells, highlighted that Th2 differentiation might involve an IL-4 positive feedback loop [10]. William Paul's group investigated this concept in a co-culture system of CD4 T cells, with a transgenic TCR specific for pigeon cytochrome $\mathrm{C}$ or chicken egg white ovalbumin (OVA) and myeloid cells. They found that low concentrations of cognate peptide induced an "early" IL-4 production that was IL-4-independent and required IL-2 mediated STAT5 activation and GATA3 induction. IL-4 signalling further up-regulated GATA3 expression via STAT6 phosphorylation and completed the Th2 differentiation process [11]. Therefore, the incipient events of Th2 polarization of a naïve CD4 T cell do not require IL-4 signalling; rather, they depend on GATA3 expression.

In vivo studies demonstrated that robust Th2 polarization could occur in an IL-4 independent manner under some circumstances [12] but still required GATA3 [13,14], which became the master regulatory transcription factor for Th2 differentiation. However, the role of IL-4 is crucial for the comprehensive manifestation of Th2 responses, including the generation of humoral immunity. As such, mice deficient in IL-4 [15], IL-4R $\alpha$ [16], or STAT6 [17-19] do not produce significant IgE and exhibit a dramatic reduction in serum levels of IgG1 following nematode infection or anti-IgD immunization in comparison with their wild-type counterparts. These findings are of particular interest for IgE-mediated diseases such as food allergy [20]. In this regard, in a model of peanut allergy, we reported that B-cell- or CD40L-deficient mice could be sensitized, as indicated by production of Th2-associated cytokines and late-phase inflammation, but did not produce IgE and IgG1 and did not undergo anaphylaxis [21]. We also recently showed that IL-4 KO mice were deficient in IgE and IgG1 production. The lack of IgE and IgG1 led to the protection of IL-4 deficient mice from food-induced anaphylaxis. We demonstrated that the critical source of IL-4 in this peanut allergy model was the naïve CD4 T cell, which effected autocrine/paracrine IL-4 signalling to amplify and stabilize the Th2 state [22].

Although the molecular mechanisms that mediate Th2 polarization have been extensively reviewed $[10,23]$, the incipient events that predispose the immune system to launch a Th2 immunity program are less understood, particularly as it refers to innocuous proteins (i.e., food allergens). Recently, we discovered that CD4 T cells carry multiple potentials and that the acquisition of a Th2 identity largely depends on the environmental cues sensed by the DC as well as the subsequent interactions that take place during allergen presentation to the impressible naïve $\mathrm{T}$ cell [20]. 


\section{On the Innocuousness of Food Allergens}

The term antigen refers to the ability of certain molecules to induce antibody generation. When an IgE response is generated against an antigen, it qualifies as an allergen. Allergens that induce IgE production and IgE-mediated allergic reactions are defined as complete (e.g., Der $\mathrm{p} 1$, Ara h 2) [24,25]; this contrasts with those not implicated in the sensitization process but are still recognized by IgE (e.g., cross-reactive allergens) [26]. The description of the hallmark features that constitute an allergen has been a recurrent area of research since the 1970s [27]. Some researchers have argued that, given the right conditions, any antigen can become an allergen [28]. However, allergen sequence analysis has demonstrated that a limited amount of protein families $(<2 \%)$ contains most of the known allergens (>700) [29], and similar findings were also reported for food allergens of plant [30] and animal origin [31]. These data indicated the existence of common structural, biochemical, and functional characteristics of food allergens in Th2 responses.

Significant effort has been dedicated to understand the biochemical alterations of allergens brought about by food processing (e.g., heat treatment, Maillard reaction, food matrix effects, etc.) as well as their digestibility [32-36] under the premise that food allergens meet the immune system first in the gastrointestinal tract. This effort ultimately concluded that the allergenicity of a given protein could not be predicted on the basis of its stability and/or digestibility alone. These factors may contribute to overall allergenicity and can be useful in the design of superior allergen preparations for immunotherapy [37] (e.g., heated and ovomucoid-depleted egg white [38,39]). However, both the detection of food allergens in the bloodstream following oral ingestion [40-43], likely via absorption through the oral mucosa [43] and the discovery of the skin as a site for allergic sensitization in humans [44-47] imply that intact food allergens reach the immune surveillance system. Therefore, the tissue microenvironment where the allergen and the immune system meet may dictate whether a Th2 response is elicited.

The immunosurveillance system largely relies on receptors that recognize pathogen- or damage-associated molecular patterns (PAMPs or DAMPs/alarmins, respectively) [48]. The innate immunostimulatory properties associated with certain food allergens may involve signalling via PAMP or DAMP receptors [49-51]. For example, TLR4, a PAMP receptor that recognizes LPS, has been linked to several allergic diseases [52]. Food allergens with lipid-binding properties (e.g., 2S albumins, non-specific lipid-binding proteins, prolamin storage proteins, etc.) may engage TLR4 signalling by binding to LPS [53]. In other cases, allergens can directly bind to the TLR4/MD-2 complex, as has been reported for $\alpha$-amylase/trypsin inhibitors [54], which are allergenic proteins of the prolamin family [55]. Through the activation of pattern recognition receptors (PRRs), allergens may create an inflammatory environment that facilitates sensitization. Specifically, invariant natural killer $\mathrm{T}$ cells recognize cow's milk sphingolipids presented via CD1d on antigen-presenting cells (APCs) and promote an environment prone for Th2 responses [56]. Interestingly, data generated with models of intragastric sensitization to $\beta$-lactoglobulin and peanut demonstrated that TLR4 was not required for IgE-responses [57-59]; however, these studies notably used the adjuvant cholera toxin (CT), which may have compensated for the lack of TLR4 [60,61].

C-type lectin receptors are a family of PAMP receptors that bind carbohydrate ligands, which are a common constituent of food allergens. Within this family, the mannose receptor was shown in vitro to mediate Ara h 1 (a major peanut allergen) internalization by human DCs [62]. Additionally, DC-SIGN was critical for Ara h 1-mediated Th2-polarization, which was lost upon Ara h 1 deglycosylation [63]. Notably, culturing DCs with antigen-coupled Lewis-x trisaccharides suppressed IL-12 production (a pro-Th1 cytokine), which is likely a relevant mechanism of Th2-polarization induced by glycans [64]. In addition, the scavenger receptor A (SR-A) family, which is specific to modified low-density lipoproteins [65], has been shown to drive uptake and MHC II presentation of OVA to OT-II CD4 T cells [66]. SR-A also mediated DC uptake of glycated OVA, which induced higher CD4 T cell responses [67] and IgE production than native OVA [68]. Evidence suggests that inherent and/or induced glycosylation of food allergens potentiates their allergenicity [62-68]. For example, advanced 
glycated end products, which are frequently produced during food processing and cooking, share their receptors with high-mobility group box protein 1 , an alarmin that promotes Th2 immunity $[69,70]$. This indicates that food allergy might be associated with high dietary advanced glycation end-products and pro-glycating dietary sugars that mimic alarmins [69,70]. However, no evidence has demonstrated that advanced glycation end products initiate food allergy; consequently, their biological relevance on the immunostimulatory properties of food allergens remains to be elucidated.

The activation of Th2 responses by allergens via DAMP receptors can involve enzymatic activity. For example, papain (papaya proteinase I) is a cysteine protease with similar enzymatic activity to that of Act $\mathrm{d} 1$ from kiwi or Ana c 2 (bromelain) from pineapple. Papain-like proteases can disturb the epithelial barrier, cause cellular damage, and the release of alarmins [52]. For example, the exposure of mouse airway epithelial cells to papain and bromelain induced the alarmins uric acid (UA), thymic stromal lymphopoietin (TSLP), and IL-33 which facilitated the generation of Th2 immunity against OVA [71]. A recent study suggested that the protease activity of papain might drive the sensitization process, reporting a reduced IgE production after subcutaneous protease inhibitor-treated papain [72]. However, another study showed that mice epicutaneously sensitized to protease inhibitor-treated papain had IgE responses comparable to those induced with the active form [73]. Accordingly, although the role of protease activity in sensitization to aeroallergens is well characterized, its role in food allergy is not yet clear [74]. Further, there is no evidence that major food allergens, such as peanut, tree-nuts, fish, and shellfish, contain enzymatic activity.

Are food proteins innocuous? On the one hand, some foods can be sensed and internalized by innate immune cells and some, especially those with protease activity, can cause damage [73,75]. On the other hand, there is extensive evidence that exposure to foods in the vast majority of individuals induces tolerance. The effectiveness of this process is attested by the prevalence of self-reported food allergy (7\%) in comparison to its much lower actual prevalence, as demonstrated by gold standard diagnostic tests, such as a controlled food allergen challenge [76-80]. Experimental models substantiate that ingestion, inhalation, or topical exposure to food antigens under homeostatic conditions is either ignored by the immune system or defaults to the induction of immunological tolerance [81-87]. Moreover, both the high prevalence of multiple food allergies within food-allergic patients and the evidence that over 170 foods can trigger allergic reactions in humans point towards an allergen-independent, mechanism-driving, allergic sensitization $[75,88]$. In summary, inherent allergenicity of foods likely represents a minor contribution to the development of food allergy. Accordingly, the ability of a given food to become an allergen may largely depend on concomitant events that subvert tissue homeostasis and produce signals that facilitate an immune response against a bystander food antigen.

\section{External Subverters of the Steady State}

Allergic sensitization is a clinically silent process and, therefore, exceedingly difficult to study in humans [89]. From this perspective, murine models have become powerful tools to identify the immunological mechanisms underlying allergic sensitization. On the basis of these experimental studies, it is possible to generate an immune response to any food when that food is administered along with an "adjuvant", which is a term derived from the Latin "adjuvare", meaning 'to aid" [90]. Certain adjuvants alter tissue homeostasis to establish conditions that result in non-specific, innate Th2 priming to bystander allergens.

The feeding or intragastric gavage of a food by itself results predominantly in immune tolerance in mice [91]. This homeostatic response can be subverted when such food is administered alongside adjuvants such as CT [21,92], which induces a strong immune response towards itself that extends to the bystander allergens. It is in the context of the CT-induced response that food allergens are taken and processed by immunosurveillance cells. Accordingly, CT has been extensively employed in models of oral sensitization to food allergens including peanut [21,93], egg [39,94,95], and milk [58,96], among others [97]. Some of the immune-stimulating effects of CT have been characterized. For example, 
CT has been shown to induce maturation and activation of DCs and promote their subsequent migration to the draining lymph nodes [98]. In a similar fashion, Shreedhar et al. reported that CT induces migration of the DCs from the subepithelial dome region of the intestine to the T- and B-cell zones of the Peyers' patches [99]. Specifically, Gustafsson et al. demonstrated that the ability of CT to activate DCs is rooted in its interaction via GM-1 ganglioside and is independent of direct activation of intestinal epithelial cells [61]. In addition, we recently demonstrated that CT induces intestinal eosinophil degranulation and release of the alarmin eosinophil peroxidase (EPO), which is critical for DC priming and allergic Th2 sensitization in the gut [100]. We have also shown that mice depleted of UA or deficient in IL-33 were protected from anaphylaxis using an intragastric sensitization protocol with CT $[59,101]$. Staphylococcus aureus, a major food contaminant which produces enterotoxin B (SEB), is another adjuvant used in models of oral sensitization [102,103]. SEB has been shown to cause Th2 polarization by upregulating the co-stimulatory molecule TIM-4 on intestinal DCs [104]. In addition, SEB upregulates IL-33 [105-107]. Additionally, MyD88-/- mice, which cannot signal through the IL-33 pathway (among others), were resistant to the effects of SEB.

Although the intragastric route has been frequently used to induce food allergy in mice, as previously mentioned, increasing evidence suggests that the skin may be a relevant route of sensitization to food allergens in humans. This has prompted the use of experimental models of epicutaneous sensitization to foods. Allergic sensitization is usually achieved by causing a barrier disruption, typically through tape stripping (TS), prior to the placement of the allergen on the skin (sometimes through a patch) [108-110]. TS, which could be considered an external subverter, induces mechanical injury, damage, and local release of IL-33 [111], UA [59] and TSLP $[108,112,113]$, etc. These alarmins are required for allergic sensitization through the priming of DCs to elicit a Th2-polarized immune response [114,115]. Notably, mice deficient in UA were protected from allergic sensitization and thus clinical reactivity [59]. The concept that alarmins are produced downstream to the external subverters (e.g., TS) and are sufficient to induce sensitization has been explored. For example, we induced allergic sensitization in mice epicutaneously exposed to peanut (no TS) in addition to subcutaneous administration of monosodium urate (i.e., UA) crystals [59]. Similarly, persistent induction of TSLP (by transgenic overexpression, injection of recombinant protein, or repeatedly stimulated epithelium) at a barrier site caused inflammation and promoted sensitization to bystander antigens [116-118].

The term 'adjuvant-free' has been used in reference to certain models of sensitization $[110,117,119]$ in which the immune response is claimed to be exclusively triggered by the food allergen. Although these models appear to be 'adjuvant-free', the molecular signature of the sensitization phase is characterized by the presence of damage and/or DAMPs. Dolence et al. demonstrated that airway exposure to peanut flour, in the absence of any adjuvant, induced peanut-specific $\operatorname{IgE}$ and anaphylaxis upon challenge [120]. However, this exposure induced the alarmins IL- $1 \alpha$ and IL- $1 \beta$, indicating that the ectopic exposure of peanut protein resulted in airway damage. Likewise, Tordesillas et al. reported an 'adjuvant-free' epicutaneous model which required the use of hair-removing depilatory cream. However, this procedure was also associated with the release of alarmins and was reliant on the IL-33-ST2 interaction in the skin-draining lymph nodes, thus intimating that the depilatory cream had inherent adjuvant effects. Interestingly, the same model was used for epicutaneous immunotherapy, suggesting that this exposure could be both sensitizing and tolerizing in different contexts [119].

\section{Converging Pathways Leading to Th2 Sensitization}

A diverse array of external subverters can specifically prime the innate immune system such that concomitant exposure to a food allergen results in a common outcome: an allergen-specific Th2 immune response. The path from diversity to commonality is illustrated in Figure 1. It proposes that certain subverters (e.g., CT, SEB, TS, etc.) establish a first degree of convergence, characterized by tissue damage and the production of an alarmin signature that may include IL-33, TSLP, IL-25, UA crystals, and EPO $[59,101,117,121]$. Although these alarmins are individually able to activate DCs, the question 
remains as to why the ultimate outcome would be a Th2 response. In such contexts, a second degree of convergence applies. Evidence suggests that many of these tissue-derived alarmins can inhibit IL-12 production. Thus, the attendant inhibition of IL-12 facilitates the adaptive immune response to become Th2-polarized [122]. In this regard, TSLP has been shown to promote Th2 immunity by conditioning DCs to downregulate IL-12 production and upregulate the costimulatory molecule OX40L [123]. IL-25 and IL-33 have been shown to induce DC OX40L [101,110]. Importantly, IL-33 has been reported as critical for Th2 polarization as well as the induction of allergen-specific IgE and anaphylaxis in models of both gut and skin allergic sensitization [101,110]. In addition to OX40L [124], the costimulatory molecules CD40 $[125,126]$ and CD80/86 $[127,128]$ on the DC are required for Th2 differentiation. As previously mentioned, UA and EPO have been reported as critical in allergic sensitization because their removal prevented it, even in the presence of an adjuvant like CT. Although experimental models of Th2 sensitization used adjuvants to cause a cascade of signalling that resulted in IL-12 inhibition, it appears that this mirrored the natural Th2 immune response to parasites. Notably, Leishmania major has been shown to block IL-12 production in macrophages and DCs [129]. The requirement of alarmins in addition to IL-12 inhibition and co-stimulation enhances the unified model of Th2 sensitization proposed by Liu et al. [130].

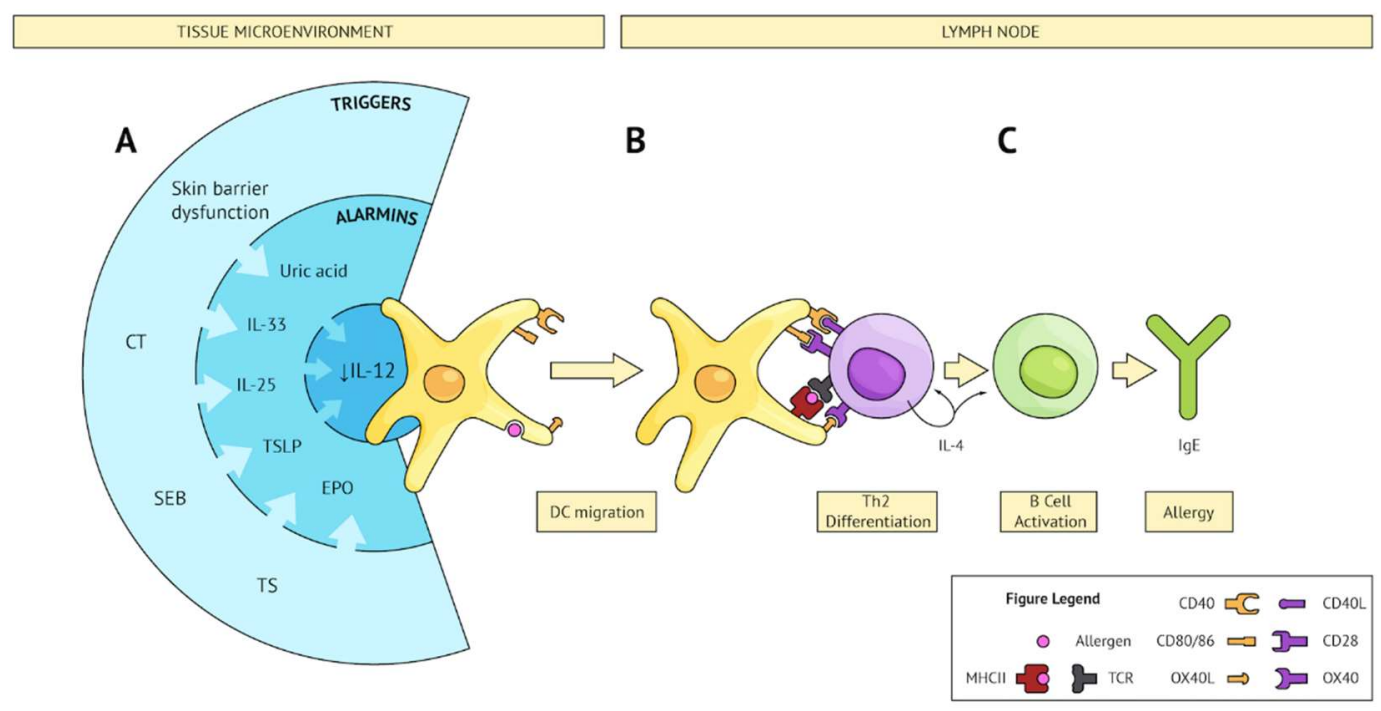

Figure 1. Converging pathways leading to Th2 sensitization. (A) Several triggers (external; e.g., CT, SEB, TS, or internal; e.g., skin barrier dysfunction) share the ability to subvert the microenvironment and produce an alarmin signature which converges on IL-12 inhibition on DCs and upregulation of Th2 polarizing co-stimulatory molecules. These activated DCs sample bystander allergens and migrate to secondary lymphoid tissue. (B) Activated DCs present allergen to cognate naïve CD4 T cells and provide co-stimulation resulting in Th2 differentiation. (C) Th2 cells activate allergen-specific B cells, leading to IgE class switching, plasma cell differentiation, and production of allergen-specific IgE.

The modulation of the innate and eventually adaptive immune response through external Th2 subverters, such as adjuvants or parasite-derived products, explains fundamental principles of Th2 priming. However, which subverters (adjuvants) facilitate the development of food allergy in humans remains obscure, largely a result of the silent nature of sensitization. A bird's eye view of the process might be enlightening. Although it is highly unlikely that $\mathrm{CT}$, a product of Vibrio cholera, plays a significant role in the development of human food allergy, CT is a member of the AB5 family of bacterial toxins [131]. Toxins belonging to this family are produced by other bacteria, including Escherichia coli, Campylobacter jejuni, Bordetella pertussis, and Shigella dysenteriae, among others [131]. In addition, SEB is a product of Staphylococcus aureus; mycotoxins produced by Fusarium species, the most frequent contaminants of crops, have been shown to promote sensitization to 
food allergens [132]. Therefore, nature affords sufficient opportunities for the exposure to toxins with the capacities documented for CT. Further, both Th2 cytokines, such as IL-4, and allergens, such as pollen, also have the capacity to inhibit IL-12 as well as directly stimulate Th2 polarization in DCs $[133,134]$. Lastly, several external subverters capable of indirectly perturbing the internal milieu may establish conditions conducive to allergic sensitization. For example, bacterial exposure early in life, antibiotic and antacid abuse during infancy, or birth through caesarean section have been associated with increased prevalence of food allergy, presumably a result of alterations to the homeostatic microbiota [135-139].

\section{Internal Subverters of the Steady State}

The genetics of allergic diseases have been long studied. In part, this is a result of the hereditability of numerous allergic diseases (i.e., allergic rhinitis, asthma, atopic dermatitis (AD)) [140]. The development of $\mathrm{AD}$ in childhood is known to be a major risk factor for later developing other allergic diseases such as asthma and, notably, food allergy (known as the atopic march) [141-143]. For example, a recent systematic review determined an odds ratio of 6.2 for self-reported food sensitization in AD versus non-AD children [141]. One gene associated with AD and food allergy is filaggrin, which maintains skin barrier integrity [144,145]. A meta-analysis by van den Oord et al. found that filaggrin gene defects were highly associated with AD development and allergic sensitization [146]. In addition, neonatal mice with filaggrin mutations ( Ft+/- Flgft Tmem79ma) developed allergic sensitization to a low dose of house dust mite plus peanut whereas wild-type animals did not [147]. $\mathrm{AD}$ has also been shown to cause tight junction dysfunction and, accordingly, an aberrant stratum corneum, which would likely facilitate epicutaneous Th2 sensitization [148]. Furthermore, a SPINK5 gene variant affecting epidermal integrity has also been associated with allergic predisposition in infants [45].

Additional mechanisms can lower the immune activation threshold and increase the risk of food allergy, as it has been shown for polymorphisms in IL-10 [149], IL-13 [150,151], IL-4 [150], IL-4R $\alpha$ [150], as well as STAT6 [152]. Likewise, polymorphisms in CD14 as well as a variant of IPEX caused by deletions in the non-coding region of FOXP3 (the master transcription factor of Treg cells) [153] are both associated with food allergy. Several of these polymorphisms have been investigated in experimental models. For example, IL-4R $\alpha$ transgenic mice $[154,155]$ exhibited a lower threshold of activation for a Th2 immune response compared to wild type animals, thus enabling IgE responses without external subversion. Lastly, primary immune deficiencies (i.e., selective IgA deficiency, hypogammaglobulinemia) as well as hyper-responsive innate immune responses have been associated with the development of allergic disease [139,156-160]. Although a comprehensive analysis of the genetics of food allergy has been reviewed elsewhere [161], these examples provide insight into the contribution of several genetic components for the development of Th2 immunity against foods. It is manifest that genetics play a role in the development of food allergy through alterations in homeostasis, which increases the risk of mounting IgE responses against food allergens. However, only a small fraction of patients with these mutations develop allergic diseases, indicating that their role in initiating food allergy is limited.

\section{Concluding Remarks}

We have proposed that neither inherent food allergenicity nor individual genetics play major roles in the induction of allergic sensitization. Thus, it stands to reason that the conceptual understanding for the initiation Th2 immunity towards food allergens merits an alternative paradigm.

Although Claude Bernard first described the concept of homeostasis in 1865, the term was coined by Walter B. Cannon in 1962. It refers to the ability of an entity, whether a cell, an organ, or an organism, to maintain an internal equilibrium despite outside changing conditions. This equilibrium, achieved by a system of feedback controls, is essential for the proper functioning of the entity. From this perspective, a disease is a loss of such equilibrium. In the context of Th2 immune responses against food allergens, 
disequilibrium can be achieved by external or internal perturbations that either activate or lower the threshold of activation of the system. Although, in immunology, the term adjuvant typically refers to any substance that activates the immune system, we suggest that any condition or intervention which tempers with the steady state could be considered an adjuvant. This phenomenon is illustrated in Figure 2 in which we propose the potential likelihood of allergic sensitization based on the varying types of subverters present in combination with the allergen.

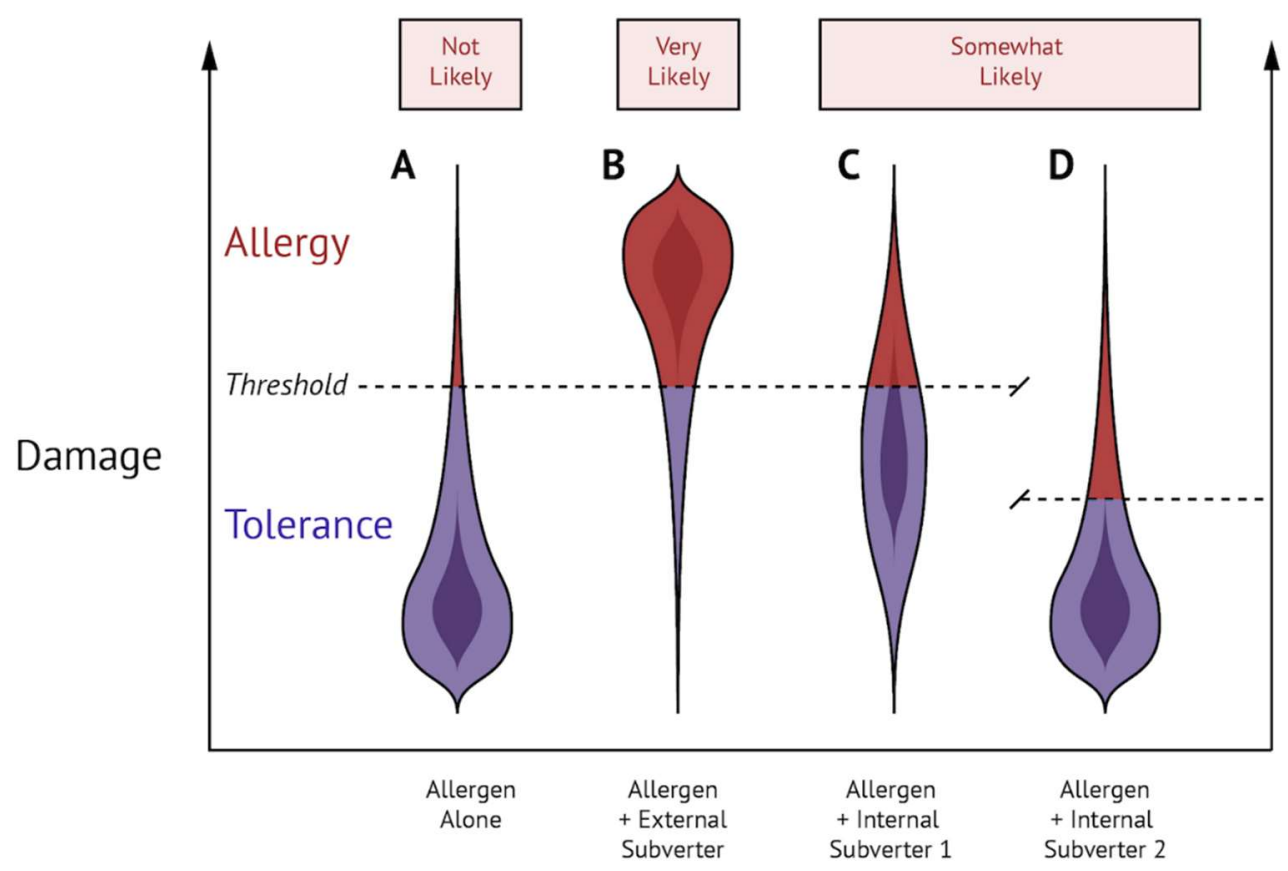

Figure 2. External and internal subversion of the steady state can lead to food allergic sensitization. (A) Allergen exposure alone results in damage that is 'not likely' sufficient to cause food allergy. (B) Exposure to allergen in combination with a Th2-inducing external subverter results in damage that is 'most likely' sufficient to cause allergy. (C,D) Exposure to allergen in combination with an internal subverter that either 1 (increases basal level of damage) or 2 (decreases the threshold of Th2 activation) is 'somewhat likely' sufficient to cause allergy.

Regardless of priming conditions and the nature of the food allergen, a convergence toward key checkpoints delineates a pathway leading to Th2 sensitization. A caveat to this paradigm is that the trajectory of food allergic disease is heterogeneous in terms of persistence of the disease, clinical reactivity, and response to treatment. At this point, the extent to which initial sensitizing conditions influence the trajectory of food allergic disease remains enigmatic.

Although food allergy has increasingly become a major health and economic concern, it remains a relatively infrequent outcome given our frequent exposure to foods. We suggest that food allergy arises as a result of the coincidence in time and space with several seemingly unconnected incidents that destroy the state of equilibrium. Exposure to a certain food in the context of a concomitant event that induces tissue damage and the subsequent production of an alarmin signature capable of inhibiting IL-12 production not only overcomes the steady state but also directs the immune system towards a Th2 pathway. The likelihood of this outcome is presumably enhanced by other contributing incidents, such as the enzymatic activity of some allergens and the lowering of internal thresholds due to genetic mutations. Beyond biology, social practices such as the abuse of antibiotics in infancy, misguided recommendations regarding the delayed introduction of foods (notably peanut) into the diet of infants, manufacturing processes that enhance food allergenicity, or the consumption of foods from contaminated crops likely play a contributory impetus. Arguably, the development of food allergies is the result of an infrequent "perfect storm". 
Author Contributions: Y.E. led the generation of the outline for the manuscript and Y.E., R.J.-S., P.S., and M.J. wrote and edited the manuscript as well as generated the figure designs. D.K.C. reviewed the manuscript and provided revisions. M.J. and S.W. supervised the entire process.

Acknowledgments: Research by the Jordana-Waserman lab cited in this work has been supported by the AllerGen NCE, Food Allergy Canada, the Delaney family, the Walter and Maria Schroeder Foundation, and the Michael Zych family. M.J. is a senior Canada Research Chair in Immunobiology of Respiratory Diseases and Allergy. We would like to thank He Tian Chen for generating the figures, and for his critical review of the manuscript.

Conflicts of Interest: The authors declare no conflict of interest.

\section{References}

1. Paul, W.E.; Zhu, J. How Are Th2-Type Immune Responses Initiated and Amplified? Nat. Rev. Immunol. 2010, 10, 225-235. [CrossRef] [PubMed]

2. Karp, C.L. Guilt by Intimate Association: What Makes an Allergen an Allergen? J. Allergy Clin. Immunol. 2010, 125, 955-960. [CrossRef] [PubMed]

3. Netea, M.G.; Joosten, L.A.B.; Latz, E.; Mills, K.H.G.; Natoli, G.; Stunnenberg, H.G.; ONeill, L.A.J.; Xavier, R.J. Trained Immunity: A Program of Innate Immune Memory in Health and Disease. Science 2016, 352, aaf1098. [CrossRef] [PubMed]

4. Mosmann, T.R.; Cherwinski, H.; Cher, D.; Coffman, R.L. Two Types of Mouse Helper T Cell Clone: Differences in B Cell Help and Lymphokine Synthesis. In Molecular Basis of Lymphokine Action; Humana Press: New York, NY, USA, 1987; pp. 149-159.

5. Romagnani, S. Human Th1 and Th2 Subsets: Doubt No More. Immunol. Today 1991, 12, 256-257. [CrossRef]

6. Romagnani, S. Immunologic Influences on Allergy and the Th1/Th2 Balance. J. Allergy Clin. Immunol. 2004, 113, 395-400. [CrossRef] [PubMed]

7. Le Gros, G. Generation of Interleukin 4 (IL-4)-Producing Cells in Vivo and in Vitro: IL-2 and IL-4 Are Required for in Vitro Generation of IL-4-Producing Cells. J. Exp. Med. 1990, 172, 921-929. [CrossRef] [PubMed]

8. Swain, S.L.; Weinberg, A.D.; English, M.; Huston, G. IL-4 Directs the Development of Th2-like Helper Effectors. J. Immunol. 1990, 145, 3796-3806. [PubMed]

9. Liao, W.; Lin, J.-X.; Leonard, W.J. IL-2 Family Cytokines: New Insights into the Complex Roles of IL-2 as a Broad Regulator of T Helper Cell Differentiation. Curr. Opin. Immunol. 2011, 23, 598-604. [CrossRef] [PubMed]

10. Paul, W.E. History of Interleukin-4. Cytokine 2015, 75, 3-7. [CrossRef] [PubMed]

11. Yamane, H.; Zhu, J.; Paul, W.E. Independent Roles for IL-2 and GATA-3 in Stimulating Naive CD4 ${ }^{+}$T Cells $^{2}$ to Generate a Th2-Inducing Cytokine Environment. J. Exp. Med. 2005, 202, 793-804. [CrossRef] [PubMed]

12. Van Panhuys, N.; Tang, S.-C.; Prout, M.; Camberis, M.; Scarlett, D.; Roberts, J.; Hu-Li, J.; Paul, W.E.; Le Gros, G. In Vivo Studies Fail to Reveal a Role for IL-4 or STAT6 Signaling in Th2 Lymphocyte Differentiation. Proc. Natl. Acad. Sci. USA 2008, 105, 12423-12428. [CrossRef] [PubMed]

13. Pai, S.-Y.; Truitt, M.L.; Ho, I.-C. GATA-3 Deficiency Abrogates the Development and Maintenance of T Helper Type 2 Cells. Proc. Natl. Acad. Sci. USA 2004, 101, 1993-1998. [CrossRef] [PubMed]

14. Zhu, J.; Min, B.; Hu-Li, J.; Watson, C.J.; Grinberg, A.; Wang, Q.; Killeen, N.; Urban, J.F.; Guo, L.; Paul, W.E. Conditional Deletion of Gata3 Shows Its Essential Function in Th1-Th2 Responses. Nat. Immunol. 2004, 5, 1157-1165. [CrossRef] [PubMed]

15. Kuhn, R.; Rajewsky, K.; Muller, W. Generation and Analysis of Interleukin-4 Deficient Mice. Science 1991, 254, 707-710. [CrossRef] [PubMed]

16. Noben-Trauth, N.; Shultz, L.D.; Brombacher, F.; Urban, J.F.; Gu, H.; Paul, W.E. An Interleukin 4 (IL-4)-Independent Pathway for CD4 ${ }^{+}$T Cell IL-4 Production Is Revealed in IL-4 Receptor-Deficient Mice. Proc. Natl. Acad. Sci. USA 1997, 94, 10838-10843. [CrossRef] [PubMed]

17. Takeda, K.; Tanaka, T.; Shi, W.; Matsumoto, M.; Minami, M.; Kashiwamura, S.; Nakanishi, K.; Yoshida, N.; Kishimoto, T.; Akira, S. Essential Role of Stat6 in IL-4 Signalling. Nature 1996, 380, 627-630. [CrossRef] [PubMed]

18. Kaplan, M.H.; Schindler, U.; Smiley, S.T.; Grusby, M.J. Stat6 Is Required for Mediating Responses to IL-4 and for the Development of Th2 Cells. Immunity 1996, 4, 313-319. [CrossRef] 
19. Shimoda, K.; van Deursent, J.; Sangster, M.Y.; Sarawar, S.R.; Carson, R.T.; Tripp, R.A.; Chu, C.; Quelle, F.W.; Nosaka, T.; Vignali, D.A.A.; et al. Lack of IL-4-Induced Th2 Response and IgE Class Switching in Mice with Disrupted State6 Gene. Nature 1996, 380, 630-633. [CrossRef] [PubMed]

20. Jiménez-Saiz, R.; Chu, D.K.; Waserman, S.J.M. Initiation, Persistence and Exacerbation of Food Allergy. In Initiation, Persistence and Exacerbation of Food Allergy; CB, S.-W., Ed.; Springer International Publishing: Cham, Switzerland, 2017; pp. 121-144.

21. Sun, J.; Arias, K.; Alvarez, D.; Fattouh, R.; Walker, T.; Goncharova, S.; Kim, B.; Waserman, S.; Reed, J.; Coyle, A.J.; et al. Impact of CD40 Ligand, B Cells, and Mast Cells in Peanut-Induced Anaphylactic Responses. J. Immunol. 2007, 179, 6696-6703. [CrossRef] [PubMed]

22. Chu, D.K.; Mohammed-Ali, Z.; Jiménez-Saiz, R.; Walker, T.D.; Goncharova, S.; Llop-Guevara, A.; Kong, J.; Gordon, M.E.; Barra, N.G.; Gillgrass, A.E.; et al. T Helper Cell IL-4 Drives Intestinal Th2 Priming to Oral Peanut Antigen, under the Control of OX40L and Independent of Innate-like Lymphocytes. Mucosal Immunol. 2014, 7, 1395-1404. [CrossRef] [PubMed]

23. Paul, W.E. What Determines Th2 Differentiation, in Vitro and in Vivo? Immunol. Cell Biol. 2010, 88, $236-239$. [CrossRef] [PubMed]

24. Aalberse, R.C. Structural Biology of Allergens. J. Allergy Clin. Immunol. 2000, 106, 228-238. [CrossRef] [PubMed]

25. McClain, S.; Bowman, C.; Fernández-Rivas, M.; Ladics, G.S.; van Ree, R. Allergic Sensitization: Food- and Protein-Related Factors. Clin. Transl. Allergy 2014, 4, 11. [CrossRef] [PubMed]

26. Sirvent, S.; Cantó, B.; Gómez, F.; Blanca, N.; Cuesta-Herranz, J.; Canto, G.; Blanca, M.; Rodríguez, R.; Villalba, M.; Palomares, O. Detailed Characterization of Act d 12 and Act d 13 from Kiwi Seeds: Implication in IgE Cross-Reactivity with Peanut and Tree Nuts. Allergy 2014, 69, 1481-1488. [CrossRef] [PubMed]

27. Aas, K. What Makes an Allergen an Allergen. Allergy 1978, 33, 3-14. [CrossRef] [PubMed]

28. Aalberse, R.C.; Crameri, R. IgE-Binding Epitopes: A Reappraisal. Allergy 2011, 66, 1261-1274. [CrossRef] [PubMed]

29. Radauer, C.; Bublin, M.; Wagner, S.; Mari, A.; Breiteneder, H. Allergens Are Distributed into Few Protein Families and Possess a Restricted Number of Biochemical Functions. J. Allergy Clin. Immunol. 2008, 121, 847-852. [CrossRef] [PubMed]

30. Jenkins, J.A.; Griffiths-Jones, S.; Shewry, P.R.; Breiteneder, H.; Mills, E.N.C. Structural Relatedness of Plant Food Allergens with Specific Reference to Cross-Reactive Allergens: An in Silico Analysis. J. Allergy Clin. Immunol. 2005, 115, 163-170. [CrossRef] [PubMed]

31. Jenkins, J.A.; Breiteneder, H.; Mills, E.N.C. Evolutionary Distance from Human Homologs Reflects Allergenicity of Animal Food Proteins. J. Allergy Clin. Immunol. 2007, 120, 1399-1405. [CrossRef] [PubMed]

32. Jiménez-Saiz, R.; Benedé, S.; Molina, E.; López-Expósito, I. Effect of Processing Technologies on the Allergenicity of Food Products. Crit. Rev. Food Sci. Nutr. 2014, 55, 1902-1917. [CrossRef] [PubMed]

33. Maleki, S.J. Food Processing: Effects on Allergenicity. Curr. Opin. Allergy Clin. Immunol. 2004, 4, $241-245$. [CrossRef] [PubMed]

34. Cabanillas, B.; Novak, N. Effects of Daily Food Processing on Allergenicity. Crit. Rev. Food Sci. Nutr. 2017, 1-12. [CrossRef] [PubMed]

35. Verhoeckx, K.C.M.; Vissers, Y.M.; Baumert, J.L.; Faludi, R.; Feys, M.; Flanagan, S.; Herouet-Guicheney, C.; Holzhauser, T.; Shimojo, R.; van der Bolt, N.; et al. Food Processing and Allergenicity. Food Chem. Toxicol. 2015, 80, 223-240. [CrossRef] [PubMed]

36. Astwood, J.D.; Leach, J.N.; Fuchs, R.L. Stability of Food Allergens to Digestion in Vitro. Nat. Biotechnol. 1996, 14, 1269-1273. [CrossRef] [PubMed]

37. Satitsuksanoa, P.; Głobińska, A.; Jansen, K.; van de Veen, W.; Akdis, M. Modified Allergens for Immunotherapy. Curr. Allergy Asthma Rep. 2018, 18. [CrossRef] [PubMed]

38. Urisu, A.; Ando, H.; Morita, Y.; Wada, E.; Yasaki, T.; Yamada, K.; Komada, K.; Torii, S.; Goto, M.; Wakamatsu, T. Allergenic Activity of Heated and Ovomucoid-Depleted Egg White. J. Allergy Clin. Immunol. 1997, 100, 171-176. [CrossRef]

39. Jiménez-Saiz, R.; Rupa, P.; Mine, Y. Immunomodulatory Effects of Heated Ovomucoid-Depleted Egg White in a BALB/c Mouse Model of Egg Allergy. J. Agric. Food Chem. 2011, 59, 13195-13202. [CrossRef] [PubMed] 
40. Husby, S.; Jensenius, J.C.; Svehag, S.-E. Passage of Undegraded Dietary Antigen into the Blood of Healthy Adults Further Characterization of the Kinetics of Uptake and the Size Distribution of the Antigen. Scand. J. Immunol. 1986, 24, 447-455. [CrossRef] [PubMed]

41. Husby, S.; Jensenius, J.C.; Svehag, S.-E. Passage of Undegraded Dietary Antigen into the Blood of Healthy Adults. Scand. J. Immunol. 1985, 22, 83-92. [CrossRef] [PubMed]

42. JanssenDuijghuijsen, L.M.; Wichers, H.J.; van Norren, K.; Keijer, J.; Baumert, J.L.; de Jong, G.A.H.; Witkamp, R.F.; Koppelman, S.J. Detection of Peanut Allergen in Human Blood after Consumption of Peanuts Is Skewed by Endogenous Immunoglobulins. J. Immunol. Methods 2017, 440, 52-57. [CrossRef] [PubMed]

43. Dirks, C.G.; Pedersen, M.H.; Platzer, M.H.; Bindslev-Jensen, C.; Skov, P.S.; Poulsen, L.K. Does Absorption across the Buccal Mucosa Explain Early Onset of Food-Induced Allergic Systemic Reactions? J. Allergy Clin. Immunol. 2005, 115, 1321-1323. [CrossRef] [PubMed]

44. Lack, G.; Fox, D.; Northstone, K.; Golding, J. Factors Associated with the Development of Peanut Allergy in Childhood. N. Engl. J. Med. 2003, 348, 977-985. [CrossRef] [PubMed]

45. Ashley, S.E.; Tan, H.-T.T.; Vuillermin, P.; Dharmage, S.C.; Tang, M.L.K.; Koplin, J.; Gurrin, L.C.; Lowe, A.; Lodge, C.; Ponsonby, A.-L.; et al. The Skin Barrier Function Gene SPINK5 Is Associated with Challenge-Proven IgE-Mediated Food Allergy in Infants. Allergy 2017, 72, 1356-1364. [CrossRef] [PubMed]

46. Brown, S.J.; Asai, Y.; Cordell, H.J.; Campbell, L.E.; Zhao, Y.; Liao, H.; Northstone, K.; Henderson, J.; Alizadehfar, R.; Ben-Shoshan, M.; et al. Loss-of-Function Variants in the Filaggrin Gene Are a Significant Risk Factor for Peanut Allergy. J. Allergy Clin. Immunol. 2011, 127, 661-667. [CrossRef] [PubMed]

47. Brough, H.A.; Liu, A.H.; Sicherer, S.; Makinson, K.; Douiri, A.; Brown, S.J.; Stephens, A.C.; Irwin McLean, W.H.; Turcanu, V.; Wood, R.A.; et al. Atopic Dermatitis Increases the Effect of Exposure to Peanut Antigen in Dust on Peanut Sensitization and Likely Peanut Allergy. J. Allergy Clin. Immunol. 2015, 135, 164-170. [CrossRef] [PubMed]

48. Medzhitov, R.; Janeway, C.J. Innate Immune Recognition: Mechanisms and Pathways. Immunol. Rev. 2000, 173, 89-97. [CrossRef] [PubMed]

49. Deifl, S.; Bohle, B. Factors Influencing the Allergenicity and Adjuvanticity of Allergens. Immunotherapy 2011, 3, 881-893. [CrossRef] [PubMed]

50. Ruiter, B.; Shreffler, W.G. Innate Immunostimulatory Properties of Allergens and Their Relevance to Food Allergy. Semin. Immunopathol. 2012, 34, 617-632. [CrossRef] [PubMed]

51. Scheurer, S.; Toda, M.; Vieths, S. What Makes an Allergen? Clin. Exp. Allergy 2015, 45, 1150-1161. [CrossRef] [PubMed]

52. Hammad, H.; Lambrecht, B.N. Barrier Epithelial Cells and the Control of Type 2 Immunity. Immunity 2015, 43, 29-40. [CrossRef] [PubMed]

53. Herre, J.; Gronlund, H.; Brooks, H.; Hopkins, L.; Waggoner, L.; Murton, B.; Gangloff, M.; Opaleye, O.; Chilvers, E.R.; Fitzgerald, K.; et al. Allergens as Immunomodulatory Proteins: The Cat Dander Protein Fel d 1 Enhances TLR Activation by Lipid Ligands. J. Immunol. 2013, 191, 1529-1535. [CrossRef] [PubMed]

54. Junker, Y.; Zeissig, S.; Kim, S.-J.; Barisani, D.; Wieser, H.; Leffler, D.A.; Zevallos, V.; Libermann, T.A.; Dillon, S.; Freitag, T.L.; et al. Wheat Amylase Trypsin Inhibitors Drive Intestinal Inflammation via Activation of Toll-like Receptor 4. J. Exp. Med. 2012, 209, 2395-2408. [CrossRef] [PubMed]

55. Salcedo, G.; Quirce, S.; Diaz-Perales, A. Wheat Allergens Associated with Baker's Asthma. J. Investig. Allergol. Clin. Immunol. 2011, 21, 81-92. [PubMed]

56. Jyonouchi, S.; Abraham, V.; Orange, J.S.; Spergel, J.M.; Gober, L.; Dudek, E.; Saltzman, R.; Nichols, K.E.; Cianferoni, A. Invariant Natural Killer T Cells from Children with versus without Food Allergy Exhibit Differential Responsiveness to Milk-Derived Sphingomyelin. J. Allergy Clin. Immunol. 2011, 128, 102-109. [CrossRef] [PubMed]

57. Bashir, M.E.H.; Louie, S.; Shi, H.N.; Nagler-Anderson, C. Toll-Like Receptor 4 Signaling by Intestinal Microbes Influences Susceptibility to Food Allergy. J. Immunol. 2004, 172, 6978-6987. [CrossRef] [PubMed]

58. Berin, M.C.; Zheng, Y.; Domaradzki, M.; Li, X.-M.; Sampson, H.A. Role of TLR4 in Allergic Sensitization to Food Proteins in Mice. Allergy 2006, 61, 64-71. [CrossRef] [PubMed]

59. Kong, J.; Chalcraft, K.; Mandur, T.S.; Jimenez-Saiz, R.; Walker, T.D.; Goncharova, S.; Gordon, M.E.; Naji, L.; Flader, K.; Larché, M.; et al. Comprehensive Metabolomics Identifies the Alarmin Uric Acid as a Critical Signal for the Induction of Peanut Allergy. Allergy 2015, 70, 495-505. [CrossRef] [PubMed] 
60. Martinon, F.; van der Goot, F.G. Did Cholera Toxin Finally Get Caught? Cell Host Microbe 2013, 13, 501-503. [CrossRef] [PubMed]

61. Gustafsson, T.; Hua, Y.-J.; Dahlgren, M.W.; Livingston, M.; Johansson-Lindbom, B.; Yrlid, U. Direct Interaction between Cholera Toxin and Dendritic Cells Is Required for Oral Adjuvant Activity. Eur. J. Immunol. 2013, 43, 1779-1788. [CrossRef] [PubMed]

62. Royer, P.-J.; Emara, M.; Yang, C.; Al-Ghouleh, A.; Tighe, P.; Jones, N.; Sewell, H.F.; Shakib, F.; Martinez-Pomares, L.; Ghaemmaghami, A.M. The Mannose Receptor Mediates the Uptake of Diverse Native Allergens by Dendritic Cells and Determines Allergen-Induced T Cell Polarization through Modulation of IDO Activity. J. Immunol. 2010, 185, 1522-1531. [CrossRef] [PubMed]

63. Shreffler, W.G.; Castro, R.R.; Kucuk, Z.Y.; Charlop-Powers, Z.; Grishina, G.; Yoo, S.; Burks, A.W.; Sampson, H.A. The Major Glycoprotein Allergen from Arachis hypogaea, Ara h 1, Is a Ligand of Dendritic Cell-Specific ICAM-Grabbing Nonintegrin and Acts as a Th2 Adjuvant In Vitro. J. Immunol. 2006, 177, 3677-3685. [CrossRef] [PubMed]

64. Hsu, S.-C.; Tsai, T.-H.; Kawasaki, H.; Chen, C.-H.; Plunkett, B.; Lee, R.T.; Lee, Y.C.; Huang, S.-K. Antigen Coupled with Lewis-X Trisaccharides Elicits Potent Immune Responses in Mice. J. Allergy Clin. Immunol. 2007, 119, 1522-1528. [CrossRef] [PubMed]

65. Canton, J.; Neculai, D.; Grinstein, S. Scavenger Receptors in Homeostasis and Immunity. Nat. Rev. Immunol. 2013, 13, 621-634. [CrossRef] [PubMed]

66. Burgdorf, S.; Kautz, A.; Bohnert, V.; Knolle, P.A.; Kurts, C. Distinct Pathways of Antigen Uptake and Intracellular Routing in CD4 and CD8 T Cell Activation. Science 2007, 316, 612-616. [CrossRef] [PubMed]

67. Ilchmann, A.; Burgdorf, S.; Scheurer, S.; Waibler, Z.; Nagai, R.; Wellner, A.; Yamamoto, Y.; Yamamoto, H.; Henle, T.; Kurts, C.; et al. Glycation of a Food Allergen by the Maillard Reaction Enhances Its T-Cell Immunogenicity: Role of Macrophage Scavenger Receptor Class A Type I and II. J. Allergy Clin. Immunol. 2010, 125, 175-183. [CrossRef] [PubMed]

68. Heilmann, M.; Wellner, A.; Gadermaier, G.; Ilchmann, A.; Briza, P.; Krause, M.; Nagai, R.; Burgdorf, S.; Scheurer, S.; Vieths, S.; et al. Ovalbumin Modified with Pyrraline, a Maillard Reaction Product, Shows Enhanced T-Cell Immunogenicity. J. Biol. Chem. 2014, 289, 7919-7928. [CrossRef] [PubMed]

69. Miller, J.D. Additional Effects of Dietary Advanced Glycation End Products. J. Allergy Clin. Immunol. 2017, 140, 319. [CrossRef] [PubMed]

70. Smith, P.K.; Masilamani, M.; Li, X.-M.; Sampson, H.A. The False Alarm Hypothesis: Food Allergy Is Associated with High Dietary Advanced Glycation End-Products and Proglycating Dietary Sugars That Mimic Alarmins. J. Allergy Clin. Immunol. 2017, 139, 429-437. [CrossRef] [PubMed]

71. Hara, K.; Iijima, K.; Elias, M.K.; Seno, S.; Tojima, I.; Kobayashi, T.; Kephart, G.M.; Kurabayashi, M.; Kita, H. Airway Uric Acid Is a Sensor of Inhaled Protease Allergens and Initiates Type 2 Immune Responses in Respiratory Mucosa. J. Immunol. 2014, 192, 4032-4042. [CrossRef] [PubMed]

72. Kamijo, S.; Suzuki, M.; Hara, M.; Shimura, S.; Ochi, H.; Maruyama, N.; Matsuda, A.; Saito, H.; Nakae, S.; Suto, H.; et al. Subcutaneous Allergic Sensitization to Protease Allergen Is Dependent on Mast Cells but Not IL-33: Distinct Mechanisms between Subcutaneous and Intranasal Routes. J. Immunol. 2016, 196, 3559-3569. [CrossRef] [PubMed]

73. Stremnitzer, C.; Manzano-Szalai, K.; Willensdorfer, A.; Starkl, P.; Pieper, M.; König, P.; Mildner, M.; Tschachler, E.; Reichart, U.; Jensen-Jarolim, E. Papain Degrades Tight Junction Proteins of Human Keratinocytes In Vitro and Sensitizes C57BL/6 Mice via the Skin Independent of Its Enzymatic Activity or TLR4 Activation. J. Investig. Dermatol. 2015, 135, 1790-1800. [CrossRef] [PubMed]

74. Lambrecht, B.N.; Hammad, H. The Immunology of Asthma. Nat. Immunol. 2014, 16, 45-56. [CrossRef] [PubMed]

75. Boye, J.I. Food Allergies in Developing and Emerging Economies: Need for Comprehensive Data on Prevalence Rates. Clin. Transl. Allergy 2012, 2, 25. [CrossRef] [PubMed]

76. Soller, L.; Ben-Shoshan, M.; Harrington, D.W.; Knoll, M.; Fragapane, J.; Joseph, L.; St Pierre, Y.; La Vieille, S.; Wilson, K.; Elliott, S.J.; et al. Adjusting for Nonresponse Bias Corrects Overestimates of Food Allergy Prevalence. J. Allergy Clin. Immunol. Pract. 2015, 3, 291-293. [CrossRef] [PubMed]

77. Soller, L.; Ben-Shoshan, M.; Harrington, D.W.; Fragapane, J.; Joseph, L.; St. Pierre, Y.; Godefroy, S.B.; La Vieille, S.; Elliott, S.J.; Clarke, A.E. Overall Prevalence of Self-Reported Food Allergy in Canada. J. Allergy Clin. Immunol. 2012, 130, 986-988. [CrossRef] [PubMed] 
78. Rona, R.J.; Keil, T.; Summers, C.; Gislason, D.; Zuidmeer, L.; Sodergren, E.; Sigurdardottir, S.T.; Lindner, T.; Goldhahn, K.; Dahlstrom, J.; et al. The Prevalence of Food Allergy: A Meta-Analysis. J. Allergy Clin. Immunol. 2007, 120, 638-646. [CrossRef] [PubMed]

79. Sicherer, S.H.; Sampson, H.A. Food Allergy: Epidemiology, Pathogenesis, Diagnosis, and Treatment. J. Allergy Clin. Immunol. 2014, 133, 291-307. [CrossRef] [PubMed]

80. Tang, M.L.K.; Mullins, R.J. Food Allergy: Is Prevalence Increasing? Intern. Med. J. 2017, 47, $256-261$. [CrossRef] [PubMed]

81. Swirski, F.K.; Gajewska, B.U.; Alvarez, D.; Ritz, S.A.; Cundall, M.J.; Cates, E.C.; Coyle, A.J.; Gutierrez-Ramos, J.-C.; Inman, M.D.; Jordana, M.; et al. Inhalation of a Harmless Antigen (Ovalbumin) Elicits Immune Activation but Divergent Immunoglobulin and Cytokine Activities in Mice. Clin. Exp. Allergy 2002, 32, 411-421. [CrossRef] [PubMed]

82. Holt, P.G.; Batty, J.E.; Turner, K.J. Inhibition of Specific IgE Responses in Mice by Pre-Exposure to Inhaled Antigen. Immunology 1981, 42, 409-417. [PubMed]

83. Agrawal, R.; Woodfolk, J.A. Skin Barrier Defects in Atopic Dermatitis. Curr. Allergy Asthma Rep. $2014,14$. [CrossRef] [PubMed]

84. Kim, K.S.; Hong, S.-W.; Han, D.; Yi, J.; Jung, J.; Yang, B.-G.; Lee, J.Y.; Lee, M.; Surh, C.D. Dietary Antigens Limit Mucosal Immunity by Inducing Regulatory T Cells in the Small Intestine. Science 2016, 351, 858-863. [CrossRef] [PubMed]

85. Pabst, O.; Mowat, A.M. Oral Tolerance to Food Protein. Mucosal Immunol. 2012, 5, 232-239. [CrossRef] [PubMed]

86. Worbs, T.; Bode, U.; Yan, S.; Hoffmann, M.W.; Hintzen, G.; Bernhardt, G.; Förster, R.; Pabst, O. Oral Tolerance Originates in the Intestinal Immune System and Relies on Antigen Carriage by Dendritic Cells. J. Exp. Med. 2006, 203, 519-527. [CrossRef] [PubMed]

87. Dunkin, D.; Berin, M.C.; Mayer, L. Allergic Sensitization Can Be Induced via Multiple Physiologic Routes in an Adjuvant-Dependent Manner. J. Allergy Clin. Immunol. 2011, 128, 1251-1258. [CrossRef] [PubMed]

88. Wang, J. Management of the Patient with Multiple Food Allergies. Curr. Allergy Asthma Rep. 2010, 10, 271-277. [CrossRef] [PubMed]

89. Monti, G.; Muratore, M.C.; Peltran, A.; Bonfante, G.; Silvestro, L.; Oggero, R.; Mussa, G.C. High Incidence of Adverse Reactions to Egg Challenge on First Known Exposure in Young Atopic Dermatitis Children: Predictive Value of Skin Prick Test and Radioallergosorbent Test to Egg Proteins. Clin. Exp. Allergy 2002, 32, 1515-1519. [CrossRef] [PubMed]

90. Awate, S.; Babiuk, L.A.; Mutwiri, G. Mechanisms of Action of Adjuvants. Front. Immunol. 2013, 4, 114. [CrossRef] [PubMed]

91. Wavrin, S.; Bernard, H.; Wal, J.-M.; Adel-Patient, K. Cutaneous or Respiratory Exposures to Peanut Allergens in Mice and Their Impacts on Subsequent Oral Exposure. Int. Arch. Allergy Immunol. 2014, 164, 189-199. [CrossRef] [PubMed]

92. Jiménez-Saiz, R.; Chu, D.K.; Mandur, T.S.; Walker, T.D.; Gordon, M.E.; Chaudhary, R.; Koenig, J.; Saliba, S.; Galipeau, H.J.; Utley, A.; et al. Lifelong Memory Responses Perpetuate Humoral Th2 Immunity and Anaphylaxis in Food Allergy. J. Allergy Clin. Immunol. 2017, 140, 1604-1615. [CrossRef] [PubMed]

93. Li, X.M.; Serebrisky, D.; Lee, S.Y.; Huang, C.K.; Bardina, L.; Schofield, B.H.; Stanley, J.S.; Burks, A.W.; Bannon, G.A.; Sampson, H.A. A Murine Model of Peanut Anaphylaxis: T- and B-Cell Responses to a Major Peanut Allergen Mimic Human Responses. J. Allergy Clin. Immunol. 2000, 106, 150-158. [CrossRef] [PubMed]

94. Snider, D.P.; Marshall, J.S.; Perdue, M.H.; Liang, H. Production of IgE Antibody and Allergic Sensitization of Intestinal and Peripheral Tissues after Oral Immunization with Protein Ag and Cholera Toxin. J. Immunol. 1994, 153, 647-657. [PubMed]

95. Pablos-Tanarro, A.; Lozano-Ojalvo, D.; Molina, E.; López-Fandiño, R. Assessment of the Allergenic Potential of the Main Egg White Proteins in BALB/c Mice. J. Agric. Food Chem. 2018. [CrossRef] [PubMed]

96. Li, X.M.; Schofield, B.H.; Huang, C.K.; Kleiner, G.I.; Sampson, H.A. A Murine Model of IgE-Mediated Cow's Milk Hypersensitivity. J. Allergy Clin. Immunol. 1999, 103 Pt 1, 206-214. [CrossRef]

97. Oyoshi, M.K.; Oettgen, H.C.; Chatila, T.A.; Geha, R.S.; Bryce, P.J. Food Allergy: Insights into Etiology, Prevention, and Treatment Provided by Murine Models. J. Allergy Clin. Immunol. 2014, 133, 309-317. [CrossRef] [PubMed] 
98. Anjuère, F.; Luci, C.; Lebens, M.; Rousseau, D.; Hervouet, C.; Milon, G.; Holmgren, J.; Ardavin, C.; Czerkinsky, C. In Vivo Adjuvant-Induced Mobilization and Maturation of Gut Dendritic Cells after Oral Administration of Cholera Toxin. J. Immunol. 2004, 173, 5103-5111. [CrossRef] [PubMed]

99. Shreedhar, V.K.; Kelsall, B.L.; Neutra, M.R. Cholera Toxin Induces Migration of Dendritic Cells from the Subepithelial Dome Region to T- and B-Cell Areas of Peyer's Patches. Infect. Immun. 2003, 71, 504-509. [CrossRef] [PubMed]

100. Chu, D.K.; Jimenez-Saiz, R.; Verschoor, C.P.; Walker, T.D.; Goncharova, S.; Llop-Guevara, A.; Shen, P.; Gordon, M.E.; Barra, N.G.; Bassett, J.D.; et al. Indigenous Enteric Eosinophils Control DCs to Initiate a Primary Th2 Immune Response in Vivo. J. Exp. Med. 2014, 211, 1657-1672. [CrossRef] [PubMed]

101. Chu, D.K.; Llop-Guevara, A.; Walker, T.D.; Flader, K.; Goncharova, S.; Boudreau, J.E.; Moore, C.L.; In, T.S.; Waserman, S.; Coyle, A.J.; et al. IL-33, but Not Thymic Stromal Lymphopoietin or IL-25, Is Central to Mite and Peanut Allergic Sensitization. J. Allergy Clin. Immunol. 2013, 131, 187-200. [CrossRef] [PubMed]

102. Liu, T.; He, S.-H.; Zheng, P.-Y.; Zhang, T.-Y.; Wang, B.-Q.; Yang, P.-C. Staphylococcal Enterotoxin B Increases TIM4 Expression in Human Dendritic Cells That Drives Naïve CD4 T Cells to Differentiate into Th2 Cells. Mol. Immunol. 2007, 44, 3580-3587. [CrossRef] [PubMed]

103. Kadariya, J.; Smith, T.C.; Thapaliya, D. Staphylococcus Aureus and Staphylococcal Food-Borne Disease: An Ongoing Challenge in Public Health. BioMed Res. Int. 2014, 2014, 827965. [CrossRef] [PubMed]

104. Yang, P.; Xing, Z.; Berin, C.M.; Soderholm, J.D.; Feng, B.; Wu, L.; Yeh, C. TIM-4 Expressed by Mucosal Dendritic Cells Plays a Critical Role in Food Antigen-Specific Th2 Differentiation and Intestinal Allergy. Gastroenterology 2007, 133, 1522-1533. [CrossRef] [PubMed]

105. Han, H.; Ziegler, S.F. Intradermal Administration of IL-33 Induces Allergic Airway Inflammation. Sci. Rep. 2017, 7, 1706. [CrossRef] [PubMed]

106. Kissner, T.L.; Moisan, L.; Mann, E.; Alam, S.; Ruthel, G.; Ulrich, R.G.; Rebek, M.; Rebek, J.; Saikh, K.U. A Small Molecule That Mimics the BB-Loop in the Toll Interleukin-1 (IL-1) Receptor Domain of MyD88 Attenuates Staphylococcal Enterotoxin B-Induced pro-Inflammatory Cytokine Production and Toxicity in Mice. J. Biol. Chem. 2011, 286, 31385-31396. [CrossRef] [PubMed]

107. Schmitz, J.; Owyang, A.; Oldham, E.; Song, Y.; Murphy, E.; McClanahan, T.K.; Zurawski, G.; Moshrefi, M.; Qin, J.; Li, X.; et al. IL-33, an Interleukin-1-like Cytokine That Signals via the IL-1 Receptor-Related Protein ST2 and Induces T Helper Type 2-Associated Cytokines. Immunity 2005, 23, 479-490. [CrossRef] [PubMed]

108. Oyoshi, M.K.; Larson, R.P.; Ziegler, S.F.; Geha, R.S. Mechanical Injury Polarizes Skin Dendritic Cells to Elicit a Th2 Response by Inducing Cutaneous Thymic Stromal Lymphopoietin Expression. J. Allergy Clin. Immunol. 2010, 126, 976-984. [CrossRef] [PubMed]

109. Bartnikas, L.M.; Gurish, M.F.; Burton, O.T.; Leisten, S.; Janssen, E.; Oettgen, H.C.; Beaupré, J.; Lewis, C.N.; Austen, K.F.; Schulte, S.; et al. Epicutaneous Sensitization Results in IgE-Dependent Intestinal Mast Cell Expansion and Food-Induced Anaphylaxis. J. Allergy Clin. Immunol. 2013, 131, 451-460. [CrossRef] [PubMed]

110. Tordesillas, L.; Goswami, R.; Benedé, S.; Grishina, G.; Dunkin, D.; Järvinen, K.M.; Maleki, S.J.; Sampson, H.A.; Berin, M.C. Skin Exposure Promotes a Th2-Dependent Sensitization to Peanut Allergens. J. Clin. Investig. 2014, 124, 4965-4975. [CrossRef] [PubMed]

111. Bruhs, A.; Proksch, E.; Schwarz, T.; Schwarz, A. Disruption of the Epidermal Barrier Induces Regulatory T Cells via IL-33 in Mice. J. Investig. Dermatol. 2018, 138, 570-579. [CrossRef] [PubMed]

112. Sano, Y.; Masuda, K.; Tamagawa-Mineoka, R.; Matsunaka, H.; Murakami, Y.; Yamashita, R.; Morita, E.; Katoh, N. Thymic Stromal Lymphopoietin Expression Is Increased in the Horny Layer of Patients with Atopic Dermatitis. Clin. Exp. Immunol. 2013, 171, 330-337. [CrossRef] [PubMed]

113. Savinko, T.; Matikainen, S.; Saarialho-Kere, U.; Lehto, M.; Wang, G.; Lehtimäki, S.; Karisola, P.; Reunala, T.; Wolff, H.; Lauerma, A.; et al. IL-33 and ST2 in Atopic Dermatitis: Expression Profiles and Modulation by Triggering Factors. J. Investig. Dermatol. 2012, 132, 1392-1400. [CrossRef] [PubMed]

114. Callard, R.E.; Harper, J.I. The skin barrier, atopic dermititis and allergy: A role for Langerhans cells? Trends Immunol. 2007, 28, 294-298. [CrossRef] [PubMed]

115. Strid, J.; Hourihane, J.; Kimber, I.; Callard, R.; Strobel, S. Distruption of the stratum corenum allows potent epicutaneous immunization with protein antigens resulting in a dominant Th2 response. Eur. J. Immunol. 2004, 34, 2100-2109. [CrossRef] [PubMed] 
116. Han, H.; Thelen, T.D.; Comeau, M.R.; Ziegler, S.F. Thymic Stromal Lymphopoietin-mediated Epicutaneous Inflammation Promotes Acute Diarrhea and Anaphylaxis. J. Clin. Investig. 2014, 124, 5442-5452. [CrossRef] [PubMed]

117. Muto, T.; Fukuoka, A.; Kabashima, K.; Ziegler, S.F.; Nakanishi, K.; Matsushita, K.; Yoshimoto, T. The Role of Basophils and Proallergic Cytokines, TSLP and IL-33, in Cutaneously Sensitized Food Allergy. Int. Immunol. 2014, 26, 539-549. [CrossRef] [PubMed]

118. Noti, M.; Kim, B.S.; Siracusa, M.C.; Rak, G.D.; Kubo, M.; Moghaddam, A.E.; Sattentau, Q.A.; Comeau, M.R.; Spergel, J.M.; Artis, D. Exposure to Food Allergens through Inflamed Skin Promotes Intestinal Food Allergy through the Thymic Stromal Lymphopoietin-Basophil Axis. J. Allergy Clin. Immunol. 2014, 133, 1390-1399. [CrossRef] [PubMed]

119. Tordesillas, L.; Mondoulet, L.; Blazquez, A.B.; Benhamou, P.-H.; Sampson, H.A.; Berin, M.C. Epicutaneous Immunotherapy Induces Gastrointestinal $\mathrm{LAP}^{+}$regulatory T Cells and Prevents Food-Induced Anaphylaxis. J. Allergy Clin. Immunol. 2017, 139, 189-201. [CrossRef] [PubMed]

120. Dolence, J.J.; Kobayashi, T.; Iijima, K.; Krempski, J.; Drake, L.Y.; Dent, A.L.; Kita, H. Airway Exposure Initiates Peanut Allergy by Involving the IL-1 Pathway and T Follicular Helper Cells in Mice. J. Allergy Clin. Immunol. 2017. [CrossRef] [PubMed]

121. Lee, J.-B. Regulation of IgE-Mediated Food Allergy by IL-9 Producing Mucosal Mast Cells and Type 2 Innate Lymphoid Cells. Immune Netw. 2016, 16, 211-218. [CrossRef] [PubMed]

122. Ria, F.; Penna, G.; Adorini, L. Th1 Cells Induce and Th2 Inhibit Antigen-Dependent IL-12 Secretion by Dendritic Cells. Eur. J. Immunol. 1998, 28, 2003-2016. [CrossRef]

123. Ito, T.; Wang, Y.-H.; Duramad, O.; Hori, T.; Delespesse, G.J.; Watanabe, N.; Qin, F.X.-F.; Yao, Z.; Cao, W.; Liu, Y.-J. TSLP-Activated Dendritic Cells Induce an Inflammatory T Helper Type 2 Cell Response through OX40 Ligand. J. Exp. Med. 2005, 202, 1213-1223. [CrossRef] [PubMed]

124. Blázquez, A.B.; Berin, M.C. Gastrointestinal Dendritic Cells Promote Th2 Skewing via OX40L. J. Immunol. 2008, 180, 4441-4450. [CrossRef] [PubMed]

125. MacDonald, A.S.; Straw, A.D.; Dalton, N.M.; Pearce, E.J. Cutting Edge: Th2 Response Induction by Dendritic Cells: A role for CD40. J. Immunol. 2002, 168, 537-540. [CrossRef] [PubMed]

126. MacDonald, A.S.; Patton, E.A.; La Flamme, A.C.; Araujo, M.I.; Huxtable, C.R.; Bauman, B.; Pearce, E.J. Impaired Th2 Development and Increased Mortality during Schistosoma mansoni Infection in the Absence of CD40/CD154 Interaction. J. Immunol. 2002, 168, 4643-4649. [CrossRef] [PubMed]

127. Hussaarts, L.; Yazdanbakhsh, M.; Guigas, B. Priming Dendritic Cells for th2 Polarization: Lessons Learned from Helminths and Implications for Metabolic Disorders. Front. Immunol. 2014, 5, 499. [CrossRef] [PubMed]

128. Li, J.-G.; Du, Y.-M.; Yan, Z.-D.; Yan, J.; Zhuansun, Y.-X.; Chen, R.; Zhang, W.; Feng, S.-L.; Ran, P.-X. CD80 and CD86 Knockdown in Dendritic Cells Regulates Th1/Th2 Cytokine Production in Asthmatic Mice. Exp. Ther. Med. 2016, 11, 878-884. [CrossRef] [PubMed]

129. Ricardo-Carter, C.; Favila, M.; Polando, R.E.; Cotton, R.N.; Bogard Horner, K.; Condon, D.; Ballhorn, W.; Whitcomb, J.P.; Yadav, M.; Geister, R.L.; et al. Leishmania Major Inhibits IL-12 in Macrophages by Signalling through CR3 (CD11b/CD18) and down-Regulation of ETS-Mediated Transcription. Parasite Immunol. 2013, 35, 409-420. [CrossRef] [PubMed]

130. Liu, Y.-J.; Soumelis, V.; Watanabe, N.; Ito, T.; Wang, Y.-H.; de Waal Malefyt, R.; Omori, M.; Zhou, B.; Ziegler, S.F. TSLP: An Epithelial Cell Cytokine That Regulates T Cell Differentiation by Conditioning Dendritic Cell Maturation. Annu. Rev. Immunol. 2007, 25, 193-219. [CrossRef] [PubMed]

131. Beddoe, T.; Paton, A.W.; Le Nours, J.; Rossjohn, J.; Paton, J.C. Structure, Biological Functions and Applications of the AB5 Toxins. Trends Biochem. Sci. 2010, 35, 411-418. [CrossRef] [PubMed]

132. Ganeshan, K.; Neilsen, C.V.; Hadsaitong, A.; Schleimer, R.P.; Luo, X.; Bryce, P.J. Impairing Oral Tolerance Promotes Allergy and Anaphylaxis: A New Murine Food Allergy Model. J. Allergy Clin. Immunol. 2009, 123, 231-238. [CrossRef] [PubMed]

133. Tada, Y.; Asahina, A.; Nakamura, K.; Tomura, M.; Fujiwara, H.; Tamaki, K. Granulocyte/macrophage Colony-Stimulating Factor Inhibits IL-12 Production of Mouse Langerhans Cells. J. Immunol. 2000, 164, 5113-5119. [CrossRef] [PubMed]

134. Traidl-Hoffmann, C.; Mariani, V.; Hochrein, H.; Karg, K.; Wagner, H.; Ring, J.; Mueller, M.J.; Jakob, T.; Behrendt, H. Pollen-Associated Phytoprostanes Inhibit Dendritic Cell Interleukin-12 Production and Augment T Helper Type 2 Cell Polarization. J. Exp. Med. 2005, 201, 627-636. [CrossRef] [PubMed] 
135. Mai, X.M.; Kull, I.; Wickman, M.; Bergström, A. Antibiotic Use in Early Life and Development of Allergic Diseases: Respiratory Infection as the Explanation. Clin Exp Allergy 2010, 40. [CrossRef] [PubMed]

136. DeMuth, K.; Stecenko, A.; Sullivan, K.; Fitzpatrick, A. Relationship between Treatment with Antacid Medication and the Prevalence of Food Allergy in Children. Allergy Asthma Proc. 2013, 34, 227-232. [CrossRef] [PubMed]

137. Untersmayr, E.; Jensen-Jarolim, E. The Role of Protein Digestibility and Antacids on Food Allergy Outcomes. J. Allergy Clin. Immunol. 2008, 121, 1301-1308. [CrossRef] [PubMed]

138. Papathoma, E.; Triga, M.; Fouzas, S.; Dimitriou, G. Cesarean Section Delivery and Development of Food Allergy and Atopic Dermatitis in Early Childhood. Pediatr. Allergy Immunol. 2016, 27, 419-424. [CrossRef] [PubMed]

139. Stein, M.M.; Hrusch, C.L.; Gozdz, J.; Igartua, C.; Pivniouk, V.; Murray, S.E.; Ledford, J.G.; Marques dos Santos, M.; Anderson, R.L.; Metwali, N.; et al. Innate Immunity and Asthma Risk in Amish and Hutterite Farm Children. N. Engl. J. Med. 2016, 375, 411-421. [CrossRef] [PubMed]

140. Ober, C.; Yao, T.-C. The Genetics of Asthma and Allergic Disease: A 21st Century Perspective. Immunol. Rev. 2011, 242, 10-30. [CrossRef] [PubMed]

141. Tsakok, T.; Marrs, T.; Mohsin, M.; Baron, S.; du Toit, G.; Till, S.; Flohr, C. Does Atopic Dermatitis Cause Food Allergy? A Systematic Review. J. Allergy Clin. Immunol. 2016, 137, 1071-1078. [CrossRef] [PubMed]

142. Werfel, T.; Breuer, K. Role of Food Allergy in Atopic Dermatitis. Curr. Opin. Allergy Clin. Immunol. 2004, 4, 379-385. [CrossRef] [PubMed]

143. Dhar, S.; Srinivas, S.M. Food Allergy in Atopic Dermatitis. Indian J. Dermatol. 2016, 61, 645-648. [CrossRef] [PubMed]

144. Sandilands, A.; Sutherland, C.; Irvine, A.D.; McLean, W.H.I. Filaggrin in the Frontline: Role in Skin Barrier Function and Disease. J. Cell Sci. 2009, 122 Pt 9, 1285-1294. [CrossRef] [PubMed]

145. Palmer, C.N.A.; Irvine, A.D.; Terron-Kwiatkowski, A.; Zhao, Y.; Liao, H.; Lee, S.P.; Goudie, D.R.; Sandilands, A.; Campbell, L.E.; Smith, F.J.D.; et al. Common Loss-of-Function Variants of the Epidermal Barrier Protein Filaggrin Are a Major Predisposing Factor for Atopic Dermatitis. Nat. Genet. 2006, 38, 441-446. [CrossRef] [PubMed]

146. Van den Oord, R.A.H.M.; Sheikh, A. Filaggrin Gene Defects and Risk of Developing Allergic Sensitisation and Allergic Disorders: Systematic Review and Meta-Analysis. BMJ 2009, 339, b2433. [CrossRef] [PubMed]

147. Walker, M.; Green, J.; Ferrie, R.; Queener, A.; Kaplan, M.H.; Cook-Mills, J.M. Mechanism for Initiation of Food Allergy: Dependence on Skin Barrier Mutations and Environmental Allergen Co-Stimulation. J. Allergy Clin. Immunol. 2018. [CrossRef] [PubMed]

148. Yuki, T.; Tobiishi, M.; Kusaka-Kikushima, A.; Ota, Y.; Tokura, Y. Impaired Tight Junctions in Atopic Dermatitis Skin and in a Skin-Equivalent Model Treated with Interleukin-17. PLoS ONE 2016, 11, e0161759. [CrossRef] [PubMed]

149. Negoro, T.; Orihara, K.; Irahara, T.; Nishiyama, H.; Hagiwara, K.; Nishida, R.; Takagi, H.; Satoh, K.; Yamamoto, Y.; Shimizu, S.; et al. Influence of SNPs in Cytokine-Related Genes on the Severity of Food Allergy and Atopic Eczema in Children. Pediatr. Allergy Immunol. 2006, 17, 583-590. [CrossRef] [PubMed]

150. Van der Pouw Kraan, T.; van Veen, A.; Boeije, L.; van Tuyl, S.; de Groot, E.; Stapel, S.; Bakker, A.; Verweij, C.; Aarden, L.; van der Zee, J. An IL-13 Promoter Polymorphism Associated with Increased Risk of Allergic Asthma. Genes Immun. 1999, 1, 61-65. [CrossRef] [PubMed]

151. Liu, X.; Beaty, T.H.; Deindl, P.; Huang, S.-K.; Lau, S.; Sommerfeld, C.; Fallin, M.D.; Kao, W.H.L.; Wahn, U.; Nickel, R. Associations between Specific Serum IgE Response and 6 Variants within the Genes IL4, IL13, and IL4RA in German Children. J. Allergy Clin. Immunol. 2004, 113, 489-495. [CrossRef] [PubMed]

152. Van Ginkel, C.D.; Pettersson, M.E.; Dubois, A.E.J.; Koppelman, G.H. Association of stat6 Gene Variants with Food Allergy Diagnosed by Double-Blind Placebo-Controlled Food Challenges. Allergy 2018. [CrossRef] [PubMed]

153. Torgerson, T.R.; Linane, A.; Moes, N.; Anover, S.; Mateo, V.; Rieux-Laucat, F.; Hermine, O.; Vijay, S.; Gambineri, E.; Cerf-Bensussan, N.; et al. Severe Food Allergy as a Variant of IPEX Syndrome Caused by a Deletion in a Noncoding Region of the FOXP3 Gene. Gastroenterology 2007, 132, 1705-1717. [CrossRef] [PubMed] 
154. Noval Rivas, M.; Burton, O.T.; Oettgen, H.C.; Chatila, T. IL-4 Production by Group 2 Innate Lymphoid Cells Promotes Food Allergy by Blocking Regulatory T-Cell Function. J. Allergy Clin. Immunol. 2016, 138, 801-811. [CrossRef] [PubMed]

155. Noval Rivas, M.; Burton, O.T.; Wise, P.; Zhang, Y.; Hobson, S.A.; Garcia Lloret, M.; Chehoud, C.; Kuczynski, J.; DeSantis, T.; Warrington, J.; et al. A Microbiota Signature Associated with Experimental Food Allergy Promotes Allergic Sensitization and Anaphylaxis. J. Allergy Clin. Immunol. 2013, 131, 201-212. [CrossRef] [PubMed]

156. Szczawińska-Popłonyk, A.; Bręborowicz, A.; Ossowska, L. Food Allergy in Children with Hypogammaglobulinemia. Pediatr. Pol. 2012, 87, 444-448. [CrossRef]

157. Tuano, K.S.; Orange, J.S.; Sullivan, K.; Cunningham-Rundles, C.; Bonilla, F.A.; Davis, C.M. Food Allergy in Patients with Primary Immunodeficiency Diseases: Prevalence within the US Immunodeficiency Network (USIDNET). J. Allergy Clin. Immunol. 2015, 135, 273-275. [CrossRef] [PubMed]

158. Neeland, M.R.; Koplin, J.J.; Dang, T.D.; Dharmage, S.C.; Tang, M.L.; Prescott, S.L.; Saffery, R.; Martino, D.J.; Allen, K.J. Early Life Innate Immune Signatures of Persistent Food Allergy. J. Allergy Clin. Immunol. 2017. [CrossRef] [PubMed]

159. Kosoy, R.; Agashe, C.; Grishin, A.; Leung, D.Y.; Wood, R.A.; Sicherer, S.H.; Jones, S.M.; Burks, A.W.; Davidson, W.F.; Lindblad, R.W.; et al. Transcriptional Profiling of Egg Allergy and Relationship to Disease Phenotype. PLoS ONE 2016, 11, e0163831. [CrossRef] [PubMed]

160. Zhang, Y.; Collier, F.; Naselli, G.; Saffery, R.; Tang, M.L.; Allen, K.J.; Ponsonby, A.-L.; Harrison, L.C.; Vuillermin, P.; BIS Investigator Group. Cord Blood Monocyte-derived Inflammatory Cytokines Suppress IL-2 and Induce Nonclassic “Th2-Type" Immunity Associated with Development of Food Allergy. Sci. Transl. Med. 2016, 8, 321ra8. [CrossRef] [PubMed]

161. Hong, X.; Tsai, H.-J.; Wang, X. Genetics of Food Allergy. Curr. Opin. Pediatr. 2009, 21, 770-776. [CrossRef] [PubMed]

(C) 2018 by the authors. Licensee MDPI, Basel, Switzerland. This article is an open access article distributed under the terms and conditions of the Creative Commons Attribution (CC BY) license (http:/ / creativecommons.org/licenses/by/4.0/). 